Durable Inequality 
This page intentionally left blank 


\title{
Durable Inequality
}

\author{
GHarles Tilly
}

University of California Press

Berkeley Los Angeles London 
The Irene Flecknoe Ross Lecture Series was established in the Department of Sociology at the University of California, Los Angeles, in 1987. The series is supported by a fund established by Ray Ross in memory of his wife, a distinguished public health nurse in Los Angeles. The lectures bring social science theory and research to bear on significant social, political, and moral issues, often in novel, even unorthodox ways. Prior Ross lecturers include Jerome Kagan, Edward Shils, S. N. Eisenstadt, William Julius Wilson, Alan Wolfe, Howard S. Becker, Craig Calhoun, and Charles Tilly.

University of California Press

Berkeley and Los Angeles, California

University of California Press, Ltd.

London, England

First Paperback Printing 1999

(C) 1998 by

The Regents of the University of California

Tilly, Charles.

Durable inequality / Charles Tilly.

p. $\mathrm{cm}$.

Includes bibliographical references and index.

ISBN 978-0-520-22170-3 (pbk. : alk. paper)

1. Income distribution. 2. Equality. I. Title.

$\mathrm{HC}_{79} \cdot \mathrm{I}_{5} \mathrm{~T}_{3} 88 \quad 1998$

$339.2-\mathrm{DC} 21$

97-31570

CIP

Printed in the United States of America

1514131211

13121110987

The paper used in this publication is both acid-free and totally chlorine-free (TCF). It meets the minimum requirements of American Standard for Information Sciences-Permanence of Paper for Printed Library Materials, ANSI Z39.48-1984. @ 
To the memory of Laurence John Tilly, 1930-1995 rugged individualist and infectious collectivist 
This page intentionally left blank 